Article

\title{
Phytoaccumulation of Copper from Irrigation Water and Its Effect on the Internal Structure of Lettuce
}

\author{
Safwan Shiyab \\ Horticulture and Crop Science, School of Agriculture, The University of Jordan, Amman 11942, Jordan; \\ safwan@ju.edu.jo
}

Received: 11 December 2017; Accepted: 7 February 2018; Published: 23 February 2018

\begin{abstract}
There is much concern about the cleanup of toxic contaminants in the environment as human activities increase. The objective of this research was to study the effects of different rates $\left(0,0.3\right.$ and $\left.0.5 \mathrm{~g} \cdot \mathrm{L}^{-1}\right)$ of $\left(\mathrm{CuCl}_{2}\right)$ used for irrigation and its translocation in shoots and roots of three varieties: Romaine lettuce (local), Redina lettuce (red) and iceberg lettuce (Lactuca sativa L.) after 97 days. There was a significant difference in fresh weight and dry weigh for all varieties of lettuce. Differential accumulation and translocation of copper $(\mathrm{Cu})$ in the root and leaf of vegetables were investigated using atomic absorption spectrophotometer. Red plant accumulated higher amounts of $\mathrm{Cu}\left(1.89 \mathrm{mg} \cdot \mathrm{kg}^{-1}\right)$ in root and $\left(0.71 \mathrm{mg} \cdot \mathrm{kg}^{-1}\right)$ in shoot compared to the other three plant species. The accumulation coefficient (AC) and translocation factor (TF) of $\mathrm{Cu}$ in three varieties was higher in red followed by local and iceberg. At high concentrations $\left(\mathrm{CuCl}_{2}: 0.5 \mathrm{~g} \cdot \mathrm{L}^{-1}\right)$, the light micrographs obtained from the leaf samples of copper-treated plants showed changes and a reduction in the number and the distribution of chloroplasts in palisade and spongy parenchyma cells. All cultivars were able to accumulate significant amounts of $\mathrm{Cu}$, but they have severe symptoms of phytotoxicity when the copper concentration was high.
\end{abstract}

Keywords: phytoremediation; lettuce; copper; microscopy

\section{Introduction}

Heavy metal accumulation in soils is one of the concerns in agricultural production due to the adverse effects on food quality and crop growth [1]. Metal-accumulating plants are directly or indirectly responsible for much of the dietary uptake of toxic heavy metals by humans and other animals [2]. Linked with environmental pollution, water pollution is a problem of worldwide concern, and ground water is extremely polluted due to unplanned disposal of industrial effluents into watercourses [3]. All heavy metals at high concentrations have strong toxic effects on biota and are regarded as environmental pollutants [4]. This contamination can be dangerous for human health, being that lettuce is one the most consumed vegetables [5]. Copper toxicity is a problem of both agricultural and environmental significance. Sources of $\mathrm{Cu}$ contamination include mining and smelting, urban, industrial and agricultural wastes and the use of agrochemicals [6]. While $\mathrm{Cu}$ is an essential micronutrient, exposure to excess $\mathrm{Cu}$ has a detrimental effect on plant growth. $\mathrm{Cu}$ acts as a structural element in regulatory proteins and participates in photosynthetic electron transport, mitochondrial respiration, oxidative stress responses, cell wall metabolism and hormone signaling $[7,8]$. Metal uptake differences of leafy vegetables are attributed to plant differences in tolerance to heavy metals [9]. Leafy vegetables are high accumulators of metal ions as compared to root vegetables and legumes [10]. Vegetables such as lettuce (Lactuca sativa L.) cultivated in wastewater-irrigated soils take up heavy metals in large enough quantities to cause potential health risks to the consumers [11]. 
The absorption capacity of heavy metals depends on the nature of vegetables, and some of them have a greater chance of accumulating a higher content of heavy metals than others [10,12]. Vegetables found in Jordan, such as lettuce, spinach, carrots, radish, cabbage, potato, tomato, turnip, etc., are commonly grown in peri-urban areas of Jordan and irrigated by city effluents. Lactuca sativa has been identified as a high biomass production plant with the capacity to accumulate high concentrations of nutrients in plant cells [13]. Because of the extensive root system, their high biomass and low-input cultivation, trees are attractive phytoremediators. Leaves can absorb gaseous heavy metals through the stomata. The use of plants in environmental cleanup of such toxic metals can guarantee a greener and cleaner planet for all of us at a lesser cost. The phytoremediation method is one of several methods for cleaning up heavy metals. Phytoremediation, i.e., using plants to remove pollutants from the environment or to render them harmless, is considered as a promising, cost-effective and environmentally-friendly technology to clean up the contaminated environment [14]. As plants are unable to avoid the absorption of heavy metals, various species have developed multiple mechanisms to tolerate them [15]. Absorption capacity of heavy metals depends on the nature of vegetables, and some of them have a greater chance to accumulation higher concentrations of heavy metals than others [16]. The phytoremediation method is one of several methods for cleaning up heavy metals. However, the objectives of this study were to measure the concentration of copper in soil and evaluate the capacity of three different selected lettuce plants to accumulate copper in their shoots and roots, as well as to identify leaf anatomic structural changes caused by copper accumulation in leaves by light microscopy.

\section{Materials and Methods}

\section{Effect of Copper in Irrigation Water on Plants' Growth}

The three varieties (Romaine lettuce (local), Redina Lettuce (red) and iceberg (ice)) of lettuce were used for the phytoaccumulation experiments that involve measures of their capacity to accumulate copper. These species were planted in pots of $25 \mathrm{~cm}$ in diameter filled with $2 \mathrm{~kg}$ of potting mix. The physical and chemical properties of the soil are presented in (Table 1). Lettuce (Lactuca sativa L.) seeds of three commercial varieties were obtained locally. Ten seeds were sown in each pot, and one plant was kept for growing for 97 days in the pot. All pots were irrigated when needed with a half liter of water with copper treatments $\left(0,0.3\right.$ and $\left.0.5 \mathrm{~g} \cdot \mathrm{L}^{-1}\right)$ of $\mathrm{CuCl}_{2}$ during the growing season. Pots with control soil samples were irrigated with tap water, which has a copper concentration of $0.13 \mathrm{mg} / \mathrm{L}$. All types of lettuce are short-day plants, which means the plants only need 10 to $12 \mathrm{~h}$ of sunlight daily. Average temperature varied from $15{ }^{\circ} \mathrm{C}$ (night) to $30^{\circ} \mathrm{C}$ (day). Shoots and roots' fresh and dry weights were recorded by using an electronic balance. After 97 days of plants cultivation in soil, leaves were cut into several discs and the fresh weight of these discs quickly obtained. Leaf discs were placed into distilled water in a covered Petri dish for $1 \mathrm{~h}$, and then, the discs were blotted dry and the "turgid weight" determined. Discs were placed in a paper bag and labeled, then put into an oven to dry. Relative water content (RWC \%) was recorded according to the formula: Relative Water Content = (Fresh wt. - Dry wt.)/(Turgid wt. - Dry wt.). All plants were grown in greenhouse conditions at Jordan University. All the treatment groups were arranged in a completely randomized design (CRD) with five replicates in each $\mathrm{Cu}$ treatment and means separated by the Duncan multiple range test at $p<0.05$. The results were analyzed by using SAS statistical software (SAS Institute Inc., Cary, NC, USA), and the least significant difference was used for comparisons between means of the treatment. 
Table 1. Some physical and chemical properties of the experimental site.

\begin{tabular}{cc}
\hline Soil Factors & Value \\
\hline Soil particle size: Sand $(\%)$ & 20 \\
Silt (\%) & 38 \\
Clay (\%) & 42 \\
Texture class & Clay loam \\
Organic matter & 1.9 \\
$\mathrm{NO}_{3}{ }^{-}(\mathrm{ppm})$ & 6.7 \\
$\mathrm{pH}$ & 12.7 \\
Mineral $\left.\mathrm{N} \mathrm{content:}^{+} \mathrm{ppm}\right)$ & 6.3 \\
Electrical conductivity $\left(\mathrm{dS} \cdot \mathrm{m}^{-1}\right)$ & 0.21 \\
Copper concentration $\left(\mathrm{mg} \cdot \mathrm{kg}^{-1}\right)$ & 3.5 \\
Extractable phosphorus $(\mathrm{ppm})$ & 17.1 \\
Extractable potassium $(\mathrm{ppm})$ & 428 \\
Bulk density $^{-1}$ & 1.02 \\
Water holding capacity & 0.35 \\
\hline
\end{tabular}

\section{Plant Samples' Analysis}

\subsection{Effect of Copper in Irrigation Water on Copper Content in Plants}

Lactuca sativa was harvested after 97 days, and various parts of the plants (shoots and roots) were separated. Plant samples were air-dried for two weeks at room temperature by spreading them on nylon fabric, followed by oven-drying at $78^{\circ} \mathrm{C}$ for $48 \mathrm{~h}$. Thereafter, the samples were ground using a mortar and pestle. For analysis, a 1.0-g dry plant sample was placed in a test tube, treated with $5 \mathrm{~mL}$ of a 5:1 mixture of aqua regia $\left(\mathrm{HNO}_{3}-\mathrm{HCl}\right)$ and perchloric acid $\left(\mathrm{HClO}_{4}\right)$ and then digested in a hot air oven at $95{ }^{\circ} \mathrm{C}$ for approximately two hours until complete digestion [12]. After digestion, the samples were left to cool and then transferred to $100-\mathrm{mL}$ volumetric flasks. The test tubes used for digestion were rinsed with distilled water, and the rinsing water was added to the volumetric flasks to make the volume up to $100 \mathrm{~mL}$. The solution was then filtered. The filtered solutions were analyzed for copper concentrations using inductively-coupled, plasma-atomic emission spectrometry (ICP-AES).

\subsection{Determination of Copper in Soil Samples}

The soil samples were oven dried at $105^{\circ} \mathrm{C}$ for $16 \mathrm{~h}$ and grounded to fine particles using a mortar and pestle. The ground particles were sieved using a 1-mm sieve. A measured quantity (2.0 g) of the soil samples was put into an acid-washed centrifuge vial (scintillation bottle). Soil samples were extracted using $35 \mathrm{~mL}$ of $0.1 \mathrm{M} \mathrm{HNO}_{3}$ at room temperature $\left(25 \pm 2{ }^{\circ} \mathrm{C}\right)$. The scintillation bottles were attached to the lid and equilibrated in an end-over-end mechanical shaker and shacked vigorously for sixteen hours; after which, the samples were centrifuged at $3000 \mathrm{rpm}$ for five minutes. The supernatant was decanted into the scintillation bottles for analysis. The analysis of the copper was done by using the Shimadzu atomic absorption spectrophotometer (Model AA6300) [17].

\subsection{Translocation Factor}

$\mathrm{Cu}$ translocation from shoot to root was measured by TF, which is given below:

$$
\mathrm{TF}=\mathrm{C} \text { shoot } / \mathrm{C} \text { root }
$$

where $C$ shoot and $C$ root are the metals' concentration in the shoot $\left(\mathrm{mg} \cdot \mathrm{kg}^{-1}\right)$ and root of the plant $\left(\mathrm{mg} \cdot \mathrm{kg}^{-1}\right)$, respectively. TF $>1$ represents that translocation of metals was effectively performed to the shoot from the root. 


\subsection{Accumulation Coefficient}

Bioaccumulation factor AC of $\mathrm{Cu}$ was calculated by:

$$
\mathrm{AC}=\mathrm{C} \text { shoot } / \mathrm{C} \text { soil }
$$

C shoot and $C$ soil are metals concentration in the plant shoot $\left(\mathrm{mg} \cdot \mathrm{kg}^{-1}\right)$ and soil $\left(\mathrm{mg} \cdot \mathrm{kg}^{-1}\right)$, respectively.

\subsection{Microscopy}

The leaf samples were excised $2 \mathrm{~cm}$ above the leaf-stem intersection of the plants for light microscopy (LM) studies. Plant samples for LM analysis were immediately fixed in formaldehyde-acetic acid (FAA) and then alcohol dehydrated, ultramicrotomed and subjected to $1 \%$ Toluidine blue staining for further observation [18].

\section{Results}

The effects of $\mathrm{CuCl}_{2}$ toxicity on the growth and morphology of lettuce are generally consistent with the reported symptoms of $\mathrm{CuCl}_{2}$ toxicity in the plants. This represented root damage, severe wilting and death of the shoot tip. There was a little chlorosis of the leaves accompanied by a pale green to white chlorosis on mature leaves. Treatment with $\mathrm{CuCl}_{2}$ caused inhibition of shoot and roots fresh and dry weight (Figures 1-4). The reduction of growth was observed at the levels of 0.3 and $0.5 \mathrm{~g} \cdot \mathrm{L}^{-1}$ of copper. At a high concentration $\left(\mathrm{CuCl}_{2}\right)$ of $0.5 \mathrm{~g} \cdot \mathrm{L}^{-1}$, all cultivars showed an effect on shoot RWC percentage (Figure 5). Copper concentration increased in soil irrigated by $\left(\mathrm{CuCl}_{2}\right) 0.5 \mathrm{~g} \cdot \mathrm{L}^{-1}$ compared to the other treatments (Figure 6). $\mathrm{CuCl}_{2}$ of $0.5 \mathrm{~g} \cdot \mathrm{L}^{-1}$ resulted in the greatest increase in shoot and root followed by the remaining treatment. Copper metal concentrations in leaves and roots of lettuce are presented in Figures 7 and 8. The highest copper concentration was in root and shoot of the red cultivar, and it ranged between $0.5 \mathrm{mg} \cdot \mathrm{kg}^{-1}$ in shoots and $1.79 \mathrm{mg} \cdot \mathrm{kg}^{-1}$ in roots. The initial plant copper content was $0.1 \mathrm{mg} \cdot \mathrm{kg}^{-1}$ and $2.3 \mathrm{mg} \cdot \mathrm{kg}^{-1}$ at the end of growing season, while the initial soil copper concentration was $3.5 \mathrm{mg} \cdot \mathrm{kg}^{-1}$, and the final soil copper concentration was $119.6 \mathrm{mg} \cdot \mathrm{kg}^{-1}$. The initial total copper in both plant and soil was $3.6 \mathrm{mg} \cdot \mathrm{kg}^{-1}$, and the final plant-soil copper was $121.9 \mathrm{mg} \cdot \mathrm{kg}^{-1}$.

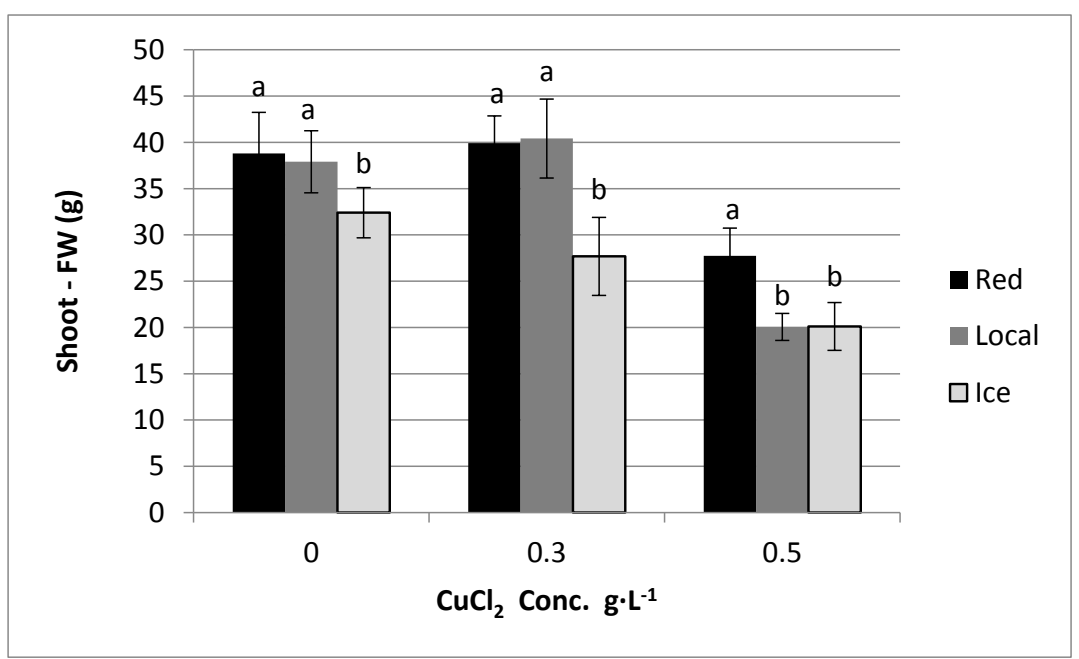

Figure 1. Effect of copper concentrations in irrigation water on shoot fresh weight of three lettuce (Lactuca sativa L.) cultivars (red, local and iceberg (Ice)) after 97 days. Means in columns with the same letters do not differ significantly at $p \leq 0.05$ level. 


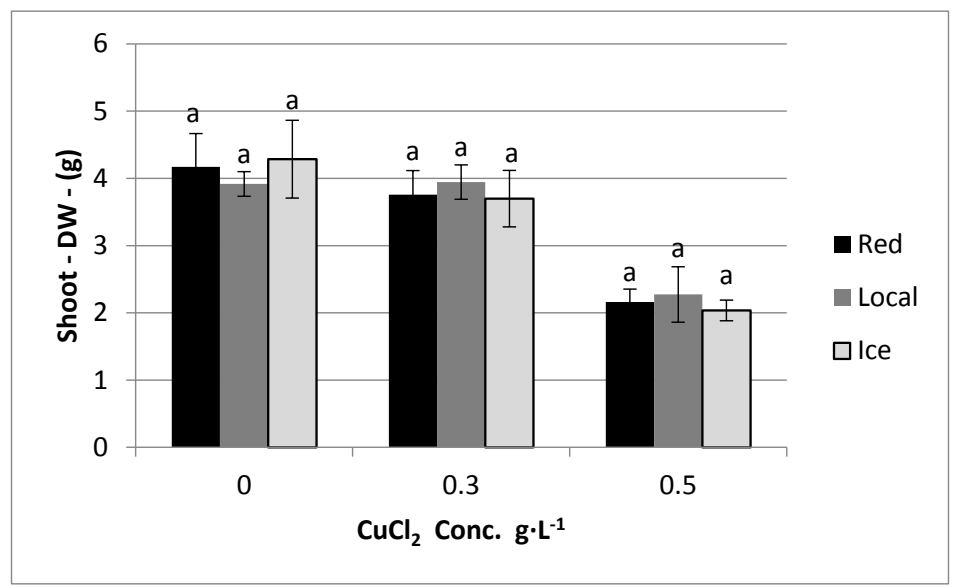

Figure 2. Effect of copper concentrations in irrigation water on shoot dry weight of three lettuce (Lactuca sativa L.) cultivars (red, local and iceberg) after 97 days. Means in columns with the same letters do not differ significantly at $p \leq 0.05$ level.

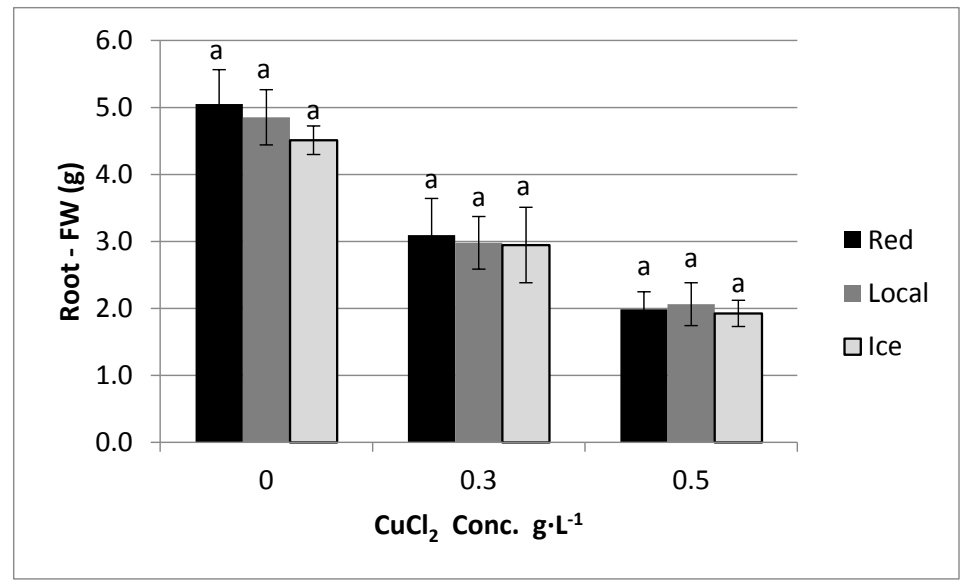

Figure 3. Effect of copper level on root fresh weight of three lettuce (Lactuca sativa L.) cultivars (red, local and iceberg) after 97 days of growth under irrigation by polluted water. Means in columns with the same letters do not differ significantly at $p \leq 0.05$ level.

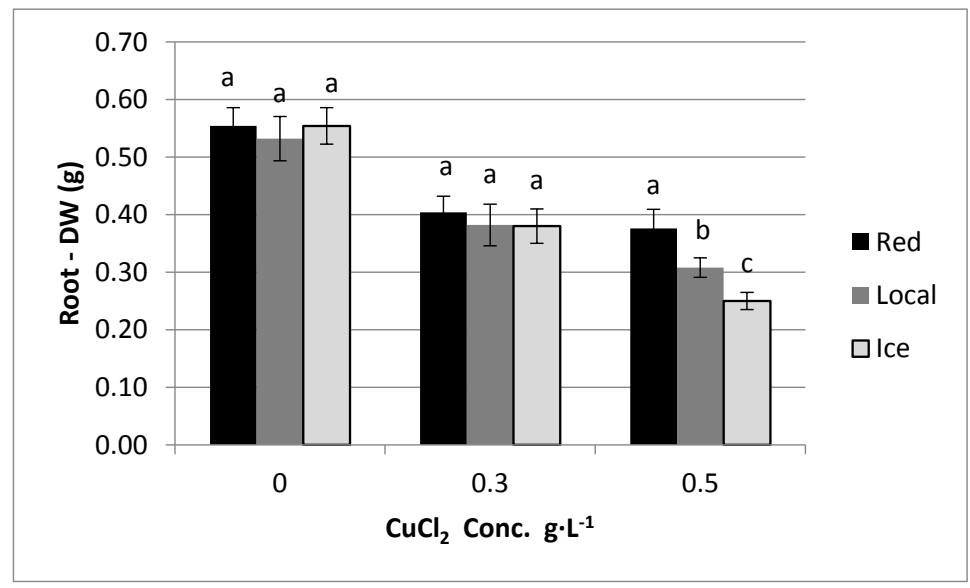

Figure 4. Effect of copper level on root dry weight of three lettuce (Lactuca sativa L.) cultivars (red, local and iceberg) after 97 days of growth under irrigation by polluted water. Means in columns with the same letters do not differ significantly at $p \leq 0.05$ level. 


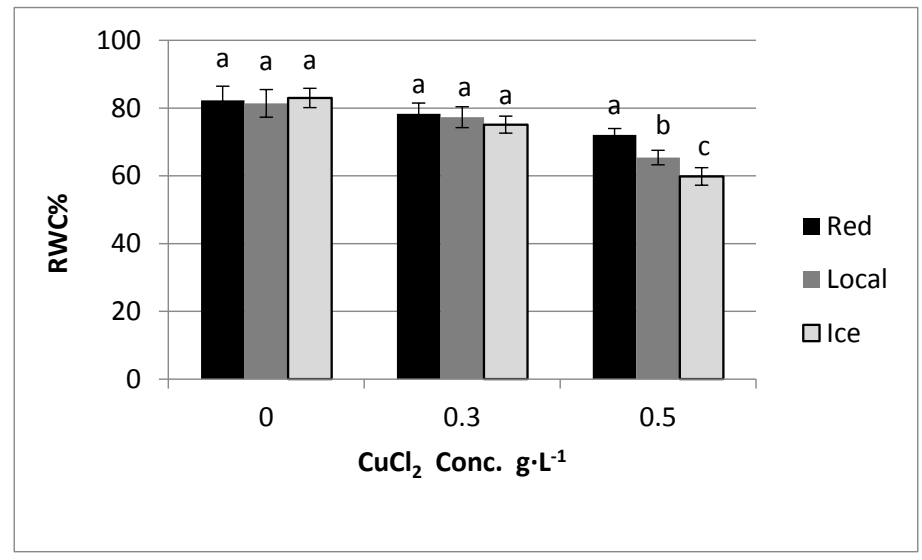

Figure 5. Relationship between relative water content (RWC \%) of shoots of lettuce (Lactuca sativa L.) cultivars (red, local and iceberg) and copper concentration. Means in columns with the same letters do not differ significantly at $p \leq 0.05$ level.

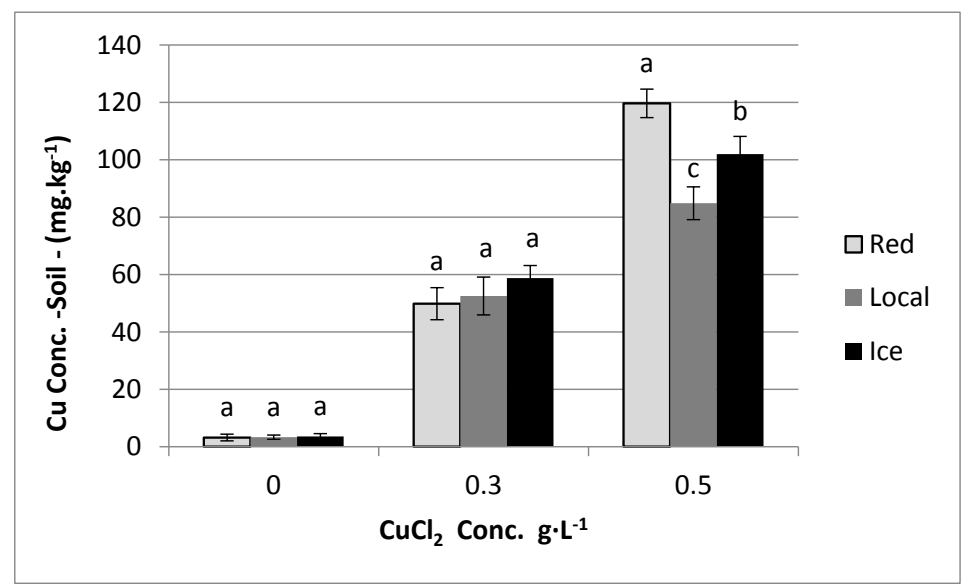

Figure 6. Mean concentration $\left(\mathrm{mg} \cdot \mathrm{kg}^{-1}\right)$ of copper of the soils in various samples used for the experiment. Means in columns with the same letters do not differ significantly at $p \leq 0.05$ level.

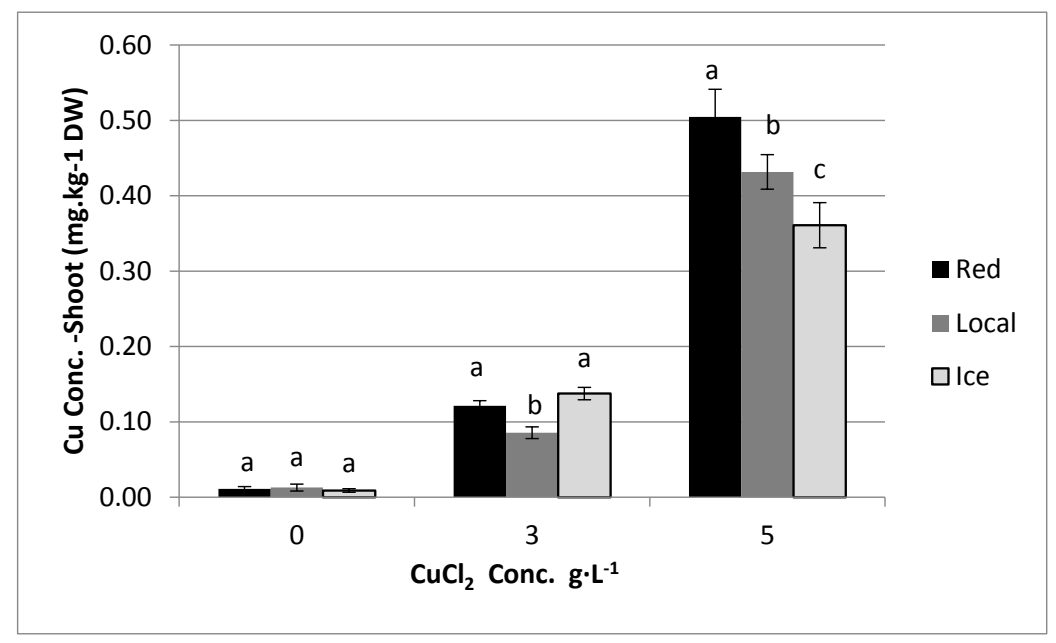

Figure 7. Mean concentration of copper content $\left(\mathrm{mg} \cdot \mathrm{kg}^{-1}\right)$ of lettuce shoot samples. Means in columns with the same letters do not differ significantly at $p \leq 0.05$ level. 


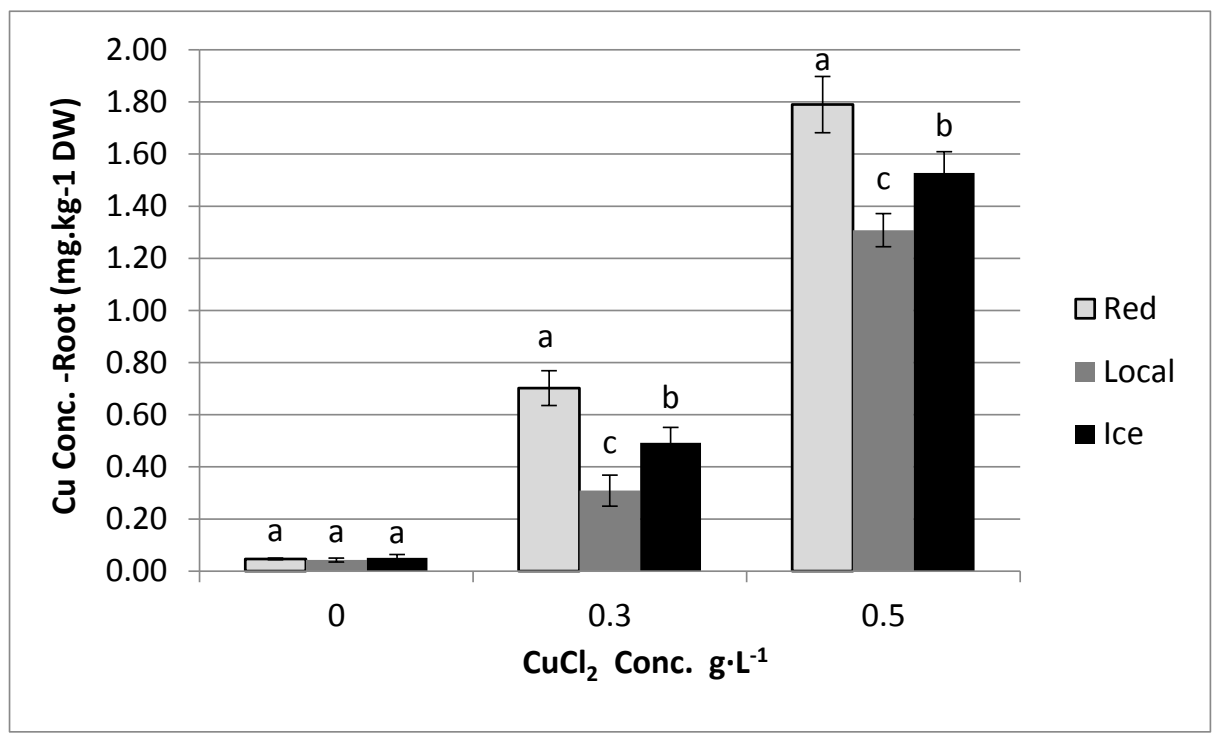

Figure 8. Mean concentration of copper content $\left(\mathrm{mg} \cdot \mathrm{kg}^{-1}\right)$ of lettuce root samples. Means in columns with the same letters do not differ significantly at $p \leq 0.05$ level.

The relationship between the translocation factor (TF) and copper concentration is shown in Figure 9. The maximum rate of TF was 0.4 with treatment of $0.5 \mathrm{~g} / \mathrm{L}$, which represents translocation of copper from root to shoot. The accumulation coefficient (AC) of $\mathrm{Cu}$ in three varieties is shown in Figure 10. It is noted that the AC was higher in red lettuce plant followed by local and iceberg.

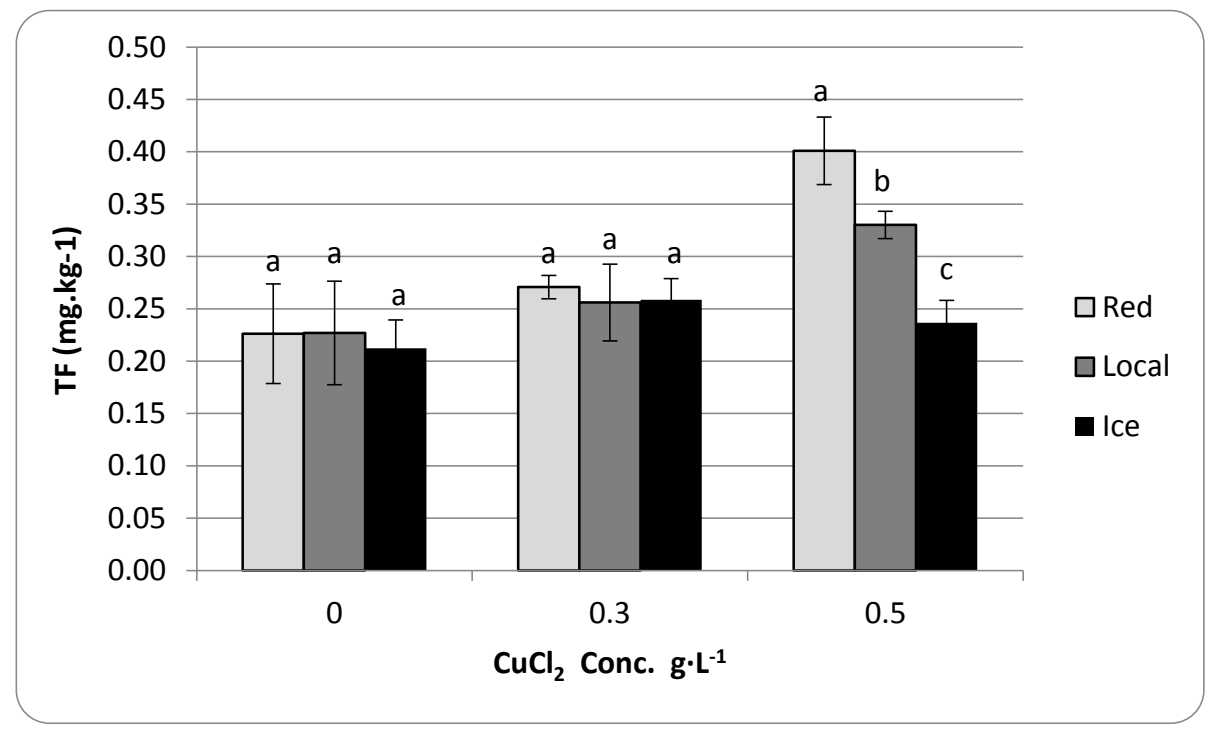

Figure 9. Relationship between the translocation factor (TF) and copper concentration. Means in columns with the same letters do not differ significantly at $p \leq 0.05$ level.

In all varieties, light micrographs of copper-treated plants (Figures 11, 12 and 13B) showed a reduction in intercellular space and thickly-stained areas along the walls of the internal cells' vessels compared to the control (Figures 11, 12 and 13A). The light micrographs of copper-treated leaves showed also shrinkage and a decrease of chloroplasts, with structural changes in both upper and lower palisade cells compared to the control group. 


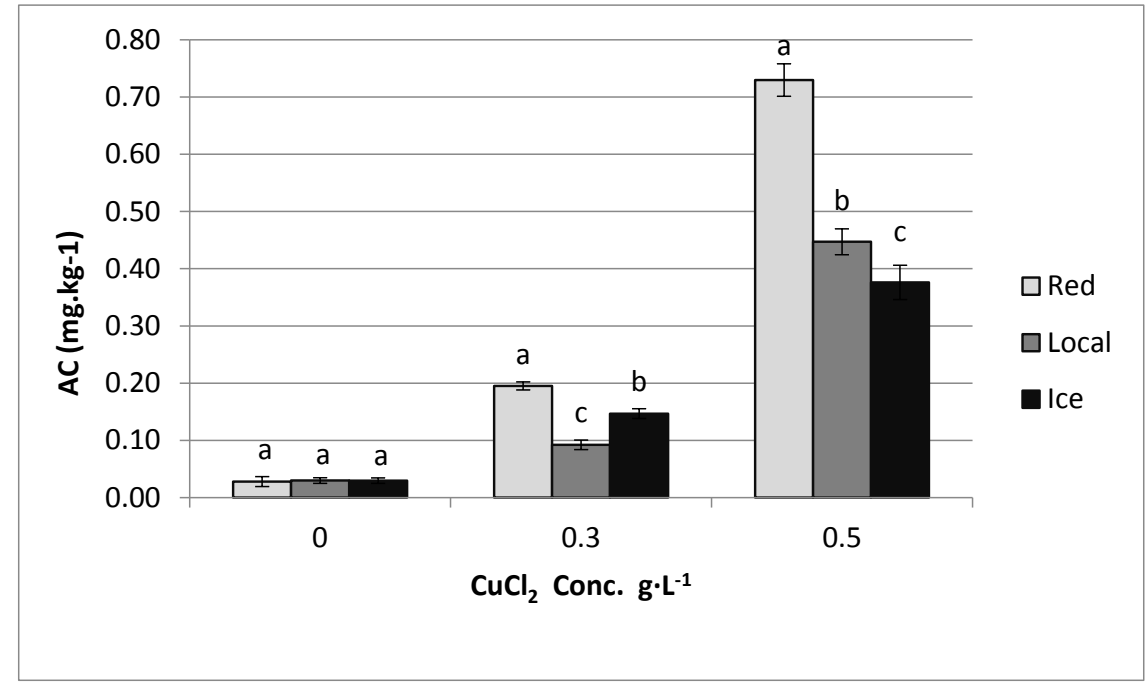

Figure 10. Relationship between the accumulation coefficient (AC) and copper concentration. Means in columns with the same letters do not differ significantly at $p \leq 0.05$ level.

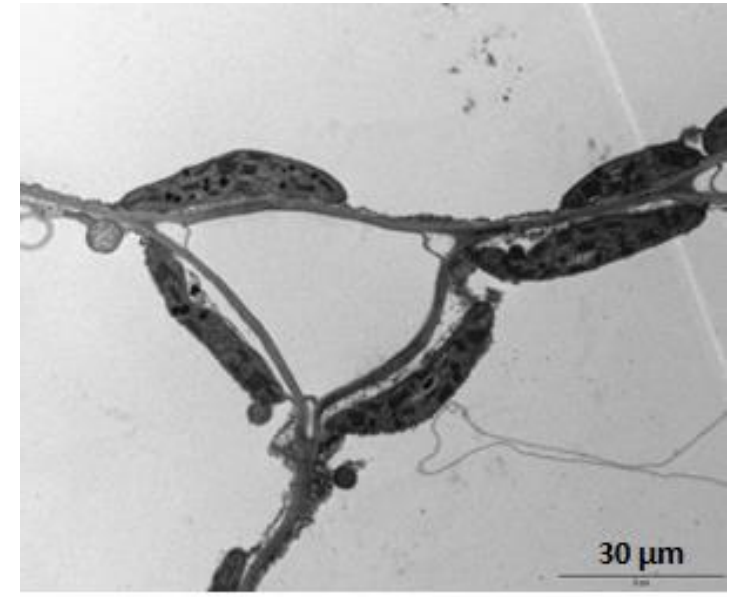

(A)

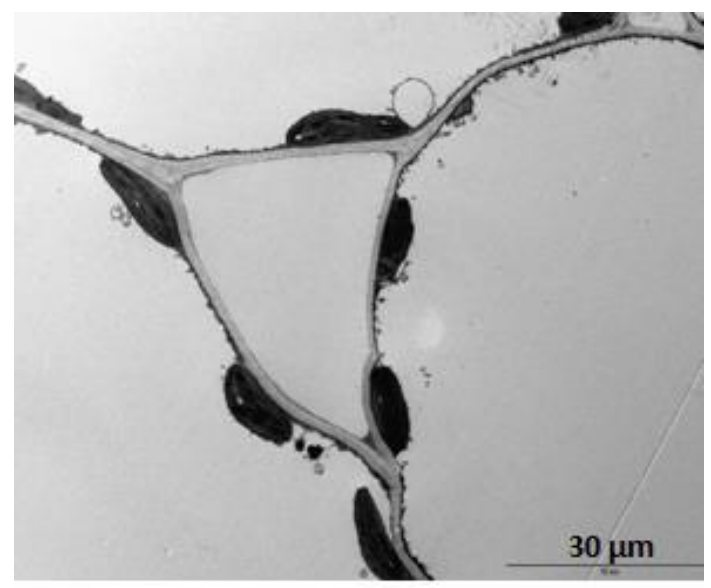

(B)

Figure 11. Light micrographs showing the chloroplast of lower palisade parenchyma cells of the $\mathrm{Cu}$-treated red cultivar (B) compared to the control (A). 


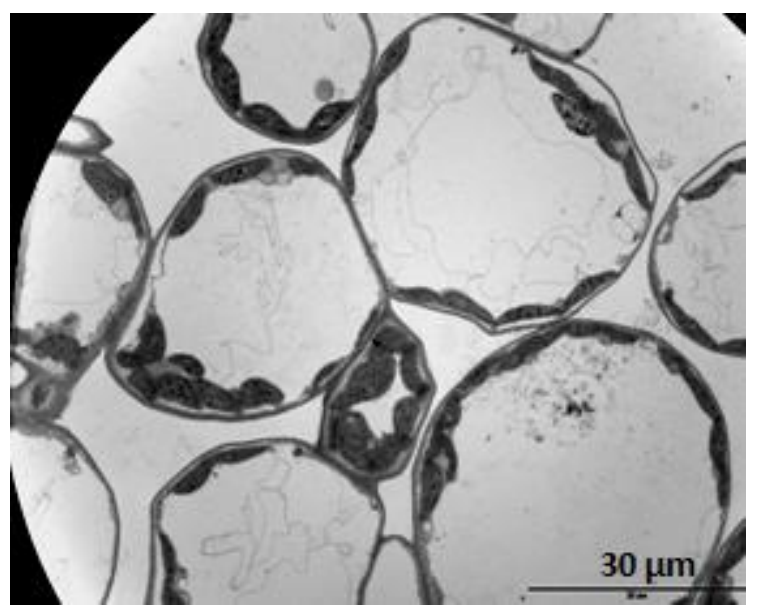

(A)

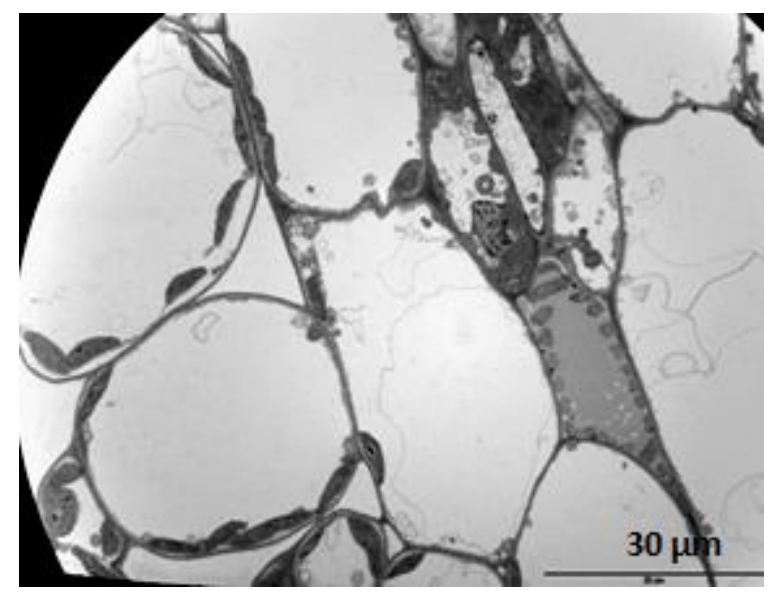

(B)

Figure 12. Light micrographs showing the chloroplast of lower palisade parenchyma cells of the Cu-treated local cultivar (B) compared to the control (A).

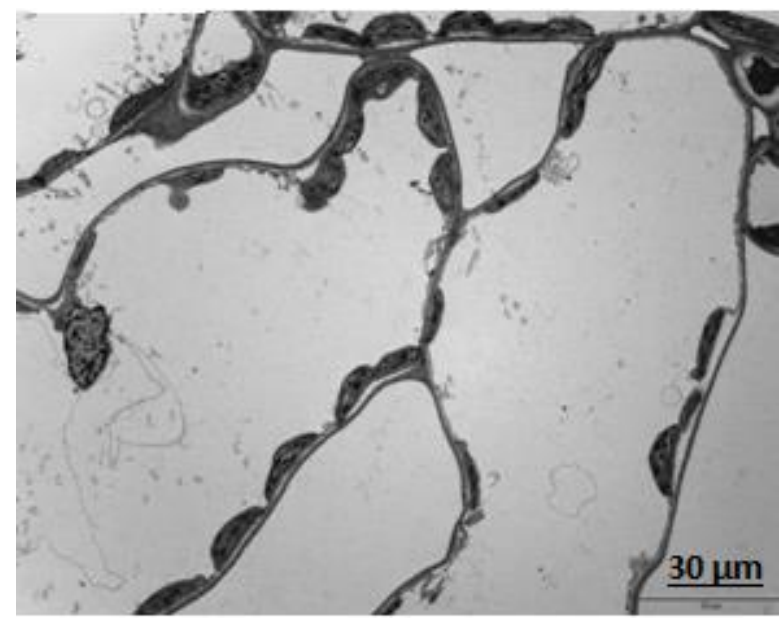

(A)

Figure 13. Cont. 


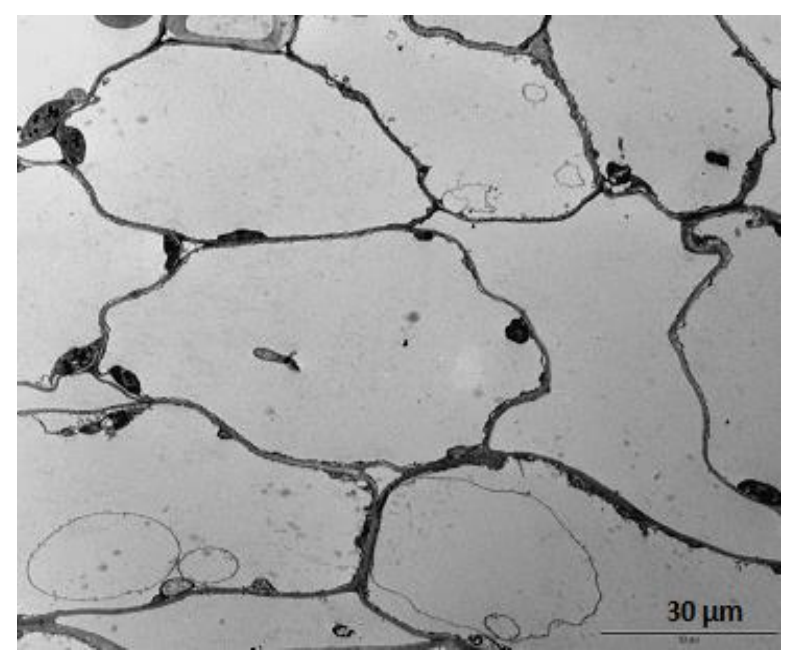

(B)

Figure 13. Light micrographs showing the chloroplast of lower palisade parenchyma cells of the $\mathrm{Cu}$-treated iceberg cultivar (B) compared to the control (A).

\section{Discussion}

Metals are significant environmental pollutants, and their toxicity is a problem of increasing significance for ecological, evolutionary, nutritional and environmental reasons. Plants take up heavy metals from the soil through different reactions such as adsorption, ionic exchange, precipitation and dissolution, among others. Some of the heavy metals are major contaminates and have toxic effects, whereas others such as $\mathrm{Cu}$ are essential for all living organisms [19]. All cultivars showed better growth in control conditions, while this was decreased with increased copper concentration. The effects of $\mathrm{Cu}$ toxicity on the growth and morphology of lettuce are generally consistent with the reported symptoms of $\mathrm{Cu}$ toxicity in other plants. It was observed that a range of morphological changes occurred in response to increasing levels of $\mathrm{Cu}$ toxicity. Genotypic effects, environmental effects and their interaction effects highly affect heavy metal uptake in crop genotypes [20-22]. The concentration of $\mathrm{Cu}$ in the root tissue was substantially higher than the shoot tissue. This is consistent with published observations that $\mathrm{Cu}$ does not tend to accumulate in the shoots $[7,23]$. This may be due to a breakdown in the $\mathrm{Cu}$ tolerance mechanisms in plant. The accumulation of $\mathrm{Cu}$ in the roots of plants used in this study is congruent with the finding of [20], who found that concentrations of $\mathrm{Cu}$ in Halimione portulacoides were different in the three parts analyzed: roots, stems and leaves. This accumulation caused a decrease in dry weight and could be due to their interference with the metabolic process associated with normal development [24]. A similar trend of the results was also obtained by $[23,25]$ for spinach and water hyacinth, respectively. A reduction of biomass of plants exposed to $\mathrm{Cu}$ stress has been also recorded in many plants (maize [26], wheat [27] and maize [28]). $\mathrm{Cu}$ is a constituent of the primary electron donor in photosystem 1 of plants. Because $\mathrm{Cu}$ can readily gain and lose an electron, it is a cofactor of oxidase, mono- and di-oxygenase (e.g., amine oxidases, ammonia monooxidase, ceruloplasmin, lysyl oxidase) and of enzymes involved in the elimination of superoxide radicals (e.g., superoxide dismutase and ascorbate oxidase). Accumulation of copper metal could be attributed to the use of effluents having a low magnitude of mentioned metals for uptake and translocation by vegetable crops. The works in [29-32] have also obtained similar results with the same reasoning for lettuce, but contrasting results $\left(12.13-32.80 \mathrm{mg} \cdot \mathrm{kg}^{-1}\right)$ were obtained by [9]. Copper caused growth retardation and resulted in clotted depositions in the vascular bundles of shoots and increases in the number of vacuoles and electron-dense materials along the walls of xylem and phloem vessels. At high concentrations, plants showed reductions in both the number of palisade and spongy parenchyma cells and cell size and number of chloroplasts. This decrease could be due to their interference with the metabolic process associated with normal development [21]. An excess of $\mathrm{Cu}$ 
in soil plays a cytotoxic role, induces stress and causes injury to plants. This leads to plant growth retardation and leaf chlorosis. Some of the direct toxic effects caused by a high metal concentration include inhibition of cytoplasmic enzymes and damage to cell structures due to oxidative stress [33-36]. Enzyme activities useful for plant metabolism may also be hampered due to heavy metal interference with the activities of soil microorganisms. Cu greatly lowered chlorophyll (Ch1) and leaf water content. Chlorophyll reduction could be due to inhibition of chlorophyll synthesis and protochlorophyllide reductase activity [37], as well as stimulation of chlorophyll-degrading chlorophyllase activity by copper [38]. It is likely that the reduction in leaf relative water content (RWC) was mainly due to harmful effects of these metals on the plasma membrane permeability of cells [39]. All physiological and biochemical processes in plants may be negatively affected by heavy metal when plants are exposed to this concentration of copper-contaminated water.

\section{Conclusions}

The research data indicated that Lactuca sativa is not a proper candidate for phytoremediation of soils with high copper concentrations. This research also discovered that the adverse influence of copper on the growth of leafy vegetables usually appears when the edible leaves begin to develop. Copper tends to accumulate in the root tissue with little translocate to the shoots. The light micrographs obtained from the leaf samples of copper-treated plants showed changes in the distribution of chloroplasts in palisade and spongy parenchyma cells. The study concluded that Lactuca sativa is seriously affected by copper at high concentrations. The data indicated that these plants may be grown directly in soils contaminated with moderate amounts of copper. The red species accumulated higher amounts of copper than local and iceberg.

Acknowledgments: This research was funded by the Deanship of Academic Research, The University of Jordan, Amman, Jordan.

Conflicts of Interest: The author declares no conflict of interest.

\section{References}

1. Naser, H.M.; Sultana, S.; Mahmud, N.; Gomes, R.; Noor, S. Heavy metal levels in vegetables with growth stage and plant species variations. Bangladesh J. Agric. Res. 2011, 36, 563-574. [CrossRef]

2. Kabata-Pendias, A.K.; Pendias, H. Trace Elements in Soils and Plants; CRC Press: Boca Raton, FL, USA, 1989; pp. 152-186.

3. Mashiatullah, A.M.; Riffat Qureshi, M.; Niaz, A.; Javed, T.; Nisar, A. Biological quality of ground water in Rawalpindi/Islamabad. Environ. Monit. 2005, 5, 13-18.

4. Chehregani, A.; Malayeri, B.; Golmohammad, R. Effect of heavy metals on the developmental stages of ovules and embryonic sac in Euphorbia cheirandenia. Pak. J. Biol. Sci. 2005, 8, 5-622.

5. Stagnitti, F. A model of the effects of nonuniform soil water distribution on the subsurface migration of bacteria: Implications for land disposal of sewage. Math. Comput. Model. 1999, 29, 41-52. [CrossRef]

6. Sauve, S.; Cook, N.; Hendershot, W.H.; McBride, M.B. Linking plant tissue concentrations and soil copper pools in urban contaminated soils. Environ. Pollut. 1996, 94, 153-157. [CrossRef]

7. Marschner, H. Mineral Nutrition of Higher Plants; Academic Press: London, UK, 1995.

8. Raven, J.A.; Evans, M.C.W.; Korb, R.E. The role of trace metals in photosynthetic electron transport in $\mathrm{O}_{2}$-evolving organisms. Photosynth. Res. 1999, 60, 111-149. [CrossRef]

9. Itanna, F. Metals in leafy vegetables grown in Addis Ababa and toxicological amplications. Ethiop. J. Health Dev. 2002, 16, 295-302. [CrossRef]

10. Alexander, P.D.; Alloway, B.J.; Dourado, A.M. Genotypic variations in the accumulation of $\mathrm{Cd}, \mathrm{Cu}, \mathrm{Pb}$ and Zn exhibited by six commonly grown vegetables. Environ. Pollut. 2006, 144, 736-745. [CrossRef] [PubMed]

11. Khan, S.; Cao, Q.; Zheng, Y.M.; Huang, Y.Z.; Zhu, Y.G. Health risks of heavy metals in contaminated soils and food crops irrigated with wastewater in Beijing, China. Environ. Pollut. 2008, 15, 686-692. [CrossRef] [PubMed] 
12. Duruibe, J.O.; Ogwuegbu, M.D.O.; Egwurugwu, J.N. Heavy metal pollution and human biotoxic effects. Int. J. Phys. Sci. 2007, 2, 112-118.

13. Kumar, N.; Dushenkov, V.; Motto, H.; Raskin, I. Phytoextraction: The use of plants to remove heavy metals from soils. Environ. Sci. Technol. 1995, 29, 1232-1238. [CrossRef] [PubMed]

14. Behrouz, E.M.; Abdolkarim, C.; Nafiseh, Y.; Bahareh, L. Identification of the hyper accumulator plants in copper and iron mine in Iran. Pak. J. Biol. Sci. 2008, 11, 490-492.

15. Lasat, M.M. Phytoextraction of toxic metals: A review of biological mechanisms. J. Environ. Qual. 2002, 31, 109-120. [CrossRef] [PubMed]

16. Nicula, C.; Peter, A.; Mihaly_Cozmuta, A. The uptake of heavy metals in Phaseolus Vulgaris and Zea Mays seeds harvested from polluted and unpolluted areas, Carpathian. J. Food Sci. Technol. 2013, 5, 1-8.

17. Tijana, M.; Dubravka, R.; Aleksandar, P. Determination of bioavailable macro- and microelements from agricultural soil using different extractants. In Proceedings of the Geophysical Research Abstracts, Vienna, Austria, 12-17 April 2005.

18. Sass, J.E. Botanical Microtechniques; Iowa St. University Press: Ames, IA, USA, 1958.

19. Antoniou, V.; Zantopoulos, N.; Tsoukapapadoulou, H. Selected heavy metal concentrations in goat liver and kidney. Vet. Hum. Toxicol. 1995, 37, 20-22. [PubMed]

20. Cheng, W.D.; Zhang, G.P.; Yao, H.G.; Wu, M.; Xu, M. Genotypic and environmental variation in cadmium, chromium, arsenic, nickel, and lead concentrations in rice grains. J. Zhejiang Univ. 2006, 7, 565-571. [CrossRef] [PubMed]

21. Zeng, F.R.; Mao, Y.; Cheng, W.D.; Wu, F.B.; Zhang, G.P. Genotypic and environmental variation in chromium, cadmium and lead concentrations in rice. Environ. Pollut. 2008, 153, 309-314. [CrossRef] [PubMed]

22. Liu, Y.; Kong, G.T.; Jia, Q.Y.; Wang, F.; Xu, R.S.; Li, F.B.; Wang, Y.; Zhou, H.R. Effects of soil properties on heavy metal accumulation in flowering Chinese cabbage (Brassica campestris L. ssp. chinensis var. utilis Tsen et Lee) in Pearl River Delta, China. J. Environ. Sci. Health Part B 2007, 42, 219-227. [CrossRef] [PubMed]

23. Loneragan, J.F. Distribution and movement of $\mathrm{Cu}$ in plants. In Copper in Soils and Plants; Loneragan, J.F., Robson, A.D., Graham, R.D., Eds.; Academic Press: Sydney, Australia, 1981.

24. Cacador, I.; Vale, C.; Catarino, F. Seasonal variations of heavy metal concentrations in plants and sediments of a Tagus estuary salt-marsh (Portugal). Heavy Met. Environ. 1995, 1, 61.

25. Lidon, F.C.; Henriques, F.S. Effects of copper on the nitrate to ammonia reduction mechanism in rice plants. Photosynthetica 1992, 26, 371-380.

26. Achakzai, A.K.K.; Bazai, Z.A. Phytoaccumulation of heavy metals in spinach (Spinacea oleracea L.) irrigated with wastewater of Quetta city. J. Chem. Soc. Pak. 2006, 28, 473-477.

27. Mohamad, H.H.; Latif, P.A. Uptake of cadmium and zinc from synthetic effluent by water hyacinth (Eichhornia crassipes). Environ. Asia 2010, 3, 36-42.

28. Liu, D.H.; Jiang, W.S.; Hou, W.Q. Uptake and accumulation of copper by roots and shoots of maize (Zea mays L). J. Environ. Sci. 2001, 13, 228-232.

29. Cook, C.M.; Vandaka, E.; Lanaras, T. Concentrations of $\mathrm{Cu}$, growth and chlorophyll content of field cultivated wheat growing in naturally enriched Cu soil. Bull. Environ. Contam. Toxicol. 1997, 58, 248-253. [CrossRef] [PubMed]

30. Dudka, S.M.; Piotrouska, M.; Chlopecka, A. Effect of elevated concentrations of Cd and Zn in soil on spring wheat yield and the metal content of the plants. Water Air Soil Pollut. 1994, 76, 333-341. [CrossRef]

31. Ramraj, A.; Afshan Gowda, T.P.H.; Karanth, N.G.K. Sorption of copper (II) and Lead (II) by microbial cultures during growth. Indian J. Environ. Health 2000, 42, 95-99.

32. Demirezen, D.; Aksoy, A. Heavy metal levels in vegetables in Turkey are within safe limits for $\mathrm{Cu}, \mathrm{Zn}, \mathrm{Ni}$ and exceeded for Cd and Pb. J. Food Qual. 2006, 29, 252-265. [CrossRef]

33. Farooq, M.; Anwar, F.; Rashid, U. Appraisal of heavy metal contents in different vegetables grown in the vicinity of an industrial area. Pak. J. Bot. 2008, 40, 2099-2106.

34. Zhuang, P.; McBride, M.B.; Xia, H.; Li, N.; Li, Z. Health risk from heavy metals via consumption of food crops in the vicinity of Dabaoshan mine South China. Sci. Total Environ. 2009, 407, 1551-1561. [CrossRef] [PubMed]

35. Crowley, D.E.; Wang, Y.V.; Reid, C.P.P.; Szansiszlo, P.J. Mechanism of iron acquisition from siderophores by microorganisms and plants. Plant Soil 1991, 130, 179-198. [CrossRef] 
36. Chlopecka, A.; Bacon, J.R.; Wilson, M.J.; Kay, J. Forms of cadmium, Lead, and Zinc in soils from southwest Potland. J. Environ. Qual. 1996, 25, 6-79. [CrossRef]

37. Stiborova, M.; Ditrichova, M.; Brezinova, A. Effects of heavy metals ions on growth and biochemical characteristics of photosynthesis of barley and maize Seedlings. Biol. Plant 1987, 29, 453-467. [CrossRef]

38. Drazkeiwice, M. Chlorophyll-occurrence, function and mechanism of action. Effects of external and internal factors. Photosynthetica 1994, 50, 321-331.

39. Ohsumi, Y.; Kitamoto, K.; Anraku, Y. Changes induced in the permeability barrier of the yeast plasma membrane by cupric ion. J. Bacteriol. 1988, 170, 2676-2682. [CrossRef] [PubMed]

C 2018 by the author. Licensee MDPI, Basel, Switzerland. This article is an open access article distributed under the terms and conditions of the Creative Commons Attribution (CC BY) license (http://creativecommons.org/licenses/by/4.0/). 